\title{
Lyell-szindróma gyermekkorban
}

\section{Lyell-syndrome in childhood}

\author{
CSOMA ZSANETT DR. ${ }^{1}$, GÁL PÉTER DR. ${ }^{2}$, MESZES ANGÉLA DR. ${ }^{1}$, \\ RÁCZ GÁBOR DR. ${ }^{2}$, RÁCZ KATALIN DR. ${ }^{2}$, TÓTH-MOLNÁR EDIT DR. ${ }^{3}$, \\ BARTHA ERIKA DR. ${ }^{3}$, VARGA ERIKA DR. ${ }^{1}$, BATA ZSUZSANNA DR. ${ }^{1}$,

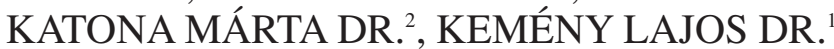

Szegedi Tudományegyetem, Szent-Györgyi Albert

Orvos- és Gyógyszertudományi Centrum,

Bôrgyógyászati és Allergológiai Klinika',

Gyermekgyógyászati Klinika és Gyermekegészségügyi Központ²,

Szemészeti Klinika ${ }^{3}$, Szeged, Magyarország

\section{ÖSSZEFOGLALÁS}

A szerzók egy 14 éves fiúgyermek esetét ismertetik. Akut felsö légúti hurut, tonsillitis miatt amoxicllin-klavulánsav és cefuroxim kezelésben részesült, illetve egy hónapja lamotrigin terápia került bevezetésre. A testfelszín több, mint 30 \%-ának denudációjával járó toxicus epidermális necrolysis diagnózisa miatt került sürgősséggel felvételre az SZTE Gyermekgyógyászati Klinika és Gyermekegészségügyi Központ Intenzív Osztályára. Nagy dózisú parenterális szteroid és intravénás immunglobulin kezelés bevezetésére került sor, amely mellett a súlyos, kiterjedt klinikai tünetek rapid javulását észlelték, ennek köszönhetöen a beteg a felvételét követö 12. napon tünetmentes állapotban otthonába exmittálható volt.

\section{Kulcsszavak: \\ toxicus epidermális necrolysis - intenzív ellátás - intravénás immunglobulin}

\section{SUMMARY}

The authors present the case of a 14-year-old boy, who had received amoxicilline-clavulanic acid and cefuroxime treatment because of an acute upper respiratory tract infection and tonsillitis 8 days before the admission; one month earlier, lamotrigine therapy had also been started. He was admitted to the Intensive Care Unit of the Department of Pediatrics with a diagnosis of toxic epidermal necrolysis, with involvement of more than $30 \%$ of the total body area. After the introduction of high-dose intravenous steroid and immunoglobulin, a rapid improvement of the severe clinical symptoms was observed, and the patient was discharged on day 12 of hospitalization.

\section{Key words: \\ toxic epidermal necrolysis - intensive care - intravenous immunoglobulin}

\section{Esetismertetés}

A 14 éves fiúgyermek felvételét megelőzően 8 nappal felsô légúti hurut, tonsillitis zajlott, emiatt a házi gyermekorvos javaslatára amoxicillin-klavulánsav terápia került bevezetésre. A gyógyszer bevezetését követôen az arcon, a nyakon, majd a felsô végtagokon erythémás, túszúrásnyi exanthemák jelentkeztek, emiatt az antibiotikum leállításra került. A gyógyszer leállítását követően azonban a bőrtünetek továbbra is progrediáltak, periorálisan, az axilláris régióban skarlát-szerú exanthema jelent meg, kifejezett tenyéri-talpi hámlással. 2 nappal később ismételten antibiotikum, cefuroxim került bevezetésre. A bő́rtünetek rapidan progrediáltak. Elesett, súlyos általános állapotban került felvételre az SZTE Gyermekgyógyászati Klinika és Gyermekegészségügyi Központ Intenzív Osztályára. A testfelszín 90\%-át meghaladó kiterjedésben kifejezetten erythemás, macolupapulosus exanthemát észleltünk, kissé szürkés, lilás, livid alaptónussal. Bőrtünetei főleg a törzs és a végtagok proximális részén konfluáló jelleget mutattak, helyenként azonban szabálytalan, atípusos target léziók is megfigyelhetőek voltak. A törzs és a végtagok területén számos petyhüdt falú, részben spontán rupturált hólyagot észleltünk. Erốteljes torok, száj, és nyelvfájdalomról számolt be, az evés, ivás igen nehezített volt. A szemhéjakon, az orron, az ajak területén erodált területek, haemorrhagiás pörkök, az orrnyálkahártya alsó részén, a buccalis és gingivális nyálkahártyán, a nyelven kiterjedt, masszív lepedékkel fedett fájdalmas eroziók, a kemény szájpadon és az uvulán petechiák alakultak ki. A conjunctivák belövelltek voltak, kis mennyiségú mucopurulens váladék távozott. A fejfájás, gyengeségérzés, folyamatos hidegrázás tovább rontották a fiatal beteg állapotát.

Rövidítések: TEN Toxicus epidermális necrolyis, IVIG Intravénás immunglobulin

Levelező szerző: Dr. Csoma Zsanett: csomazs@mail.derma.szote.u-szeged.hu 
Korábbi anamnézise szerint kisiskolás kora óta elrévedéseket észleltek, absence epilepsia miatt 10 éves kora óta valproátot szedett, amelynek dózisát fokozatosan lecsökkentették, majd elhagyták. Iskolai teljesítményromlás miatt 1 hónapja lamotriginre történt az antiepilepticum leváltása, 50 mg-os kezdő dózisban, fokozatos heti dózisemeléssel; felvételét megelőzően 2x100 mg-os dózisban kapta a gyógyszert.

Tekintettel az anamnézisre, valamint a jellegzetes klinikai tünetekre, toxicus epidermális necrolysis (TEN) diagnózisa merült fel, ennek megfelelően kezdtük el a beteg speciális ellátását. Elsô lépésként a betegnél valamennyi, korábban bevezetett gyógyszer leállításra került. Az intenzív osztályos ellátás biztosításához és a vitális paraméterek monitorizálásához artéria és centrális véna kanülálás, húgyúti katéter felhelyezése történt. A kanülöket öltésekkel rögzítettük, ragasztást nem használtunk. A kiterjedt bőrfelületi érintettségre való tekintettel emelt dózisú folyadékterápiát kezdtünk, melyet az égett betegek ellátásában használt, módosított Parkland formula alapján számoltunk, de a folyadékpótlási tervet kissé csökkentve indítottuk el, és a későbbiekben az óradiurézis függvényében módosítottuk. Az alkalmazott folyadékterápia mellett vitális paraméterei egyensúlyban voltak, keringéstámogató kezelést nem igényelt. A fájdalomcsillapítás céljából a beteg érkezésekor bólusban, majd folyamatos infúzióban morphin adására került sor. Tekintettel a szájnyálkahártya érintettségére, korai enterális táplálás bevezetése nem volt lehetséges, ezért parenterális táplálást építettünk föl. Fertőzés profilaxis céljából vancomycin kezelést, majd antimycotikus terápiát kezdtünk. Felvételének napján nagy dózisú parenterális methylprednisolon kezelést indítottunk (125 mg Solu-Medrol, 2 mg/tskg), majd tekintettel a bőrtünetek progressziójára, a bullosus, illetve denudált területek kiterjedésének fokozódására a felvételt követő 3. napon nagy dózisú intravénás immunglobulin (IVIG) kezelés
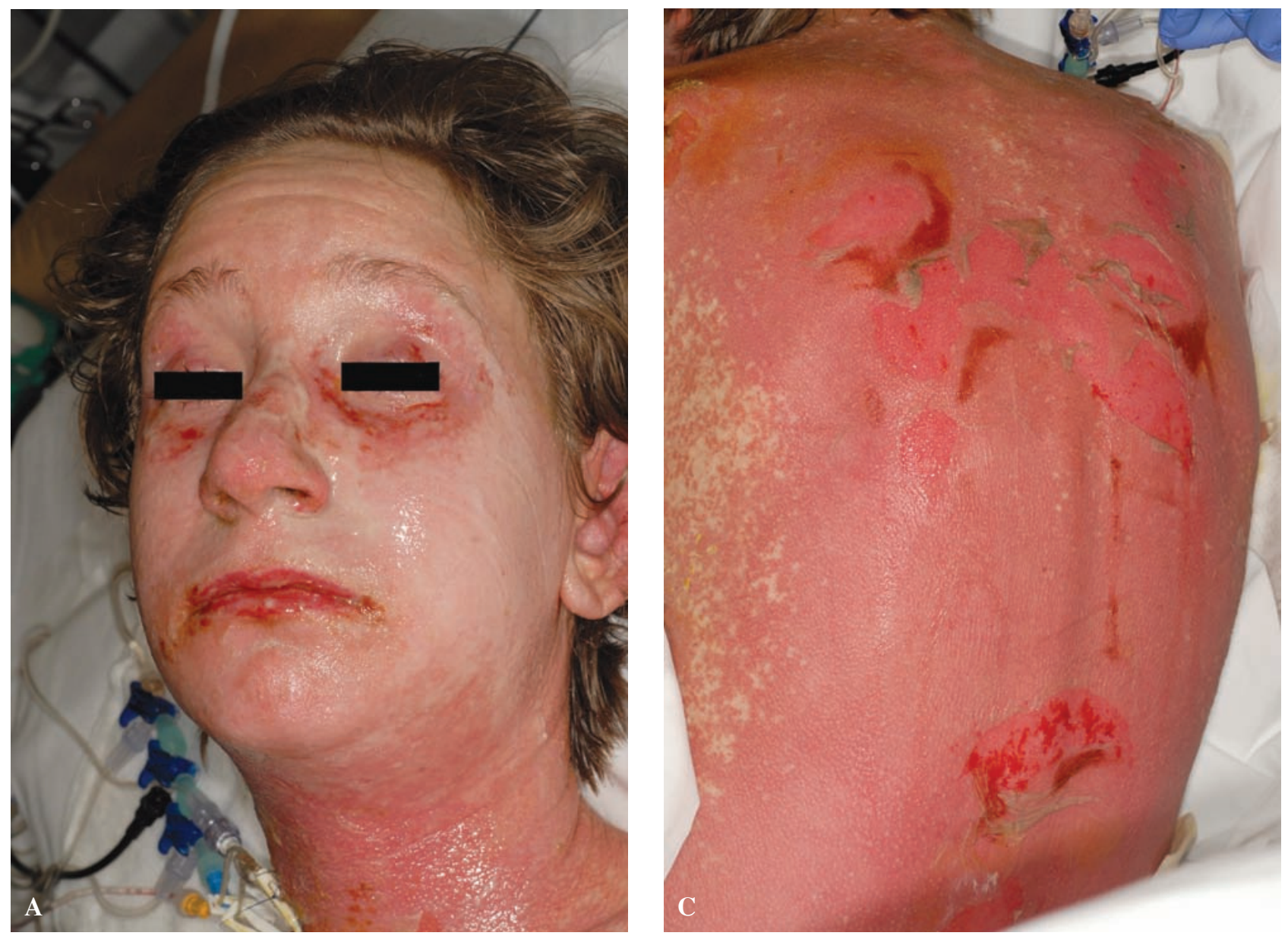

1. A, B, C ábra

Maximális intenzitású tünetek a 3. napon. Erodált, fájdalmas, felszínesen hámfosztott területek az arc, az ajak- és szájnyálkahártya, valamint a hát területén 

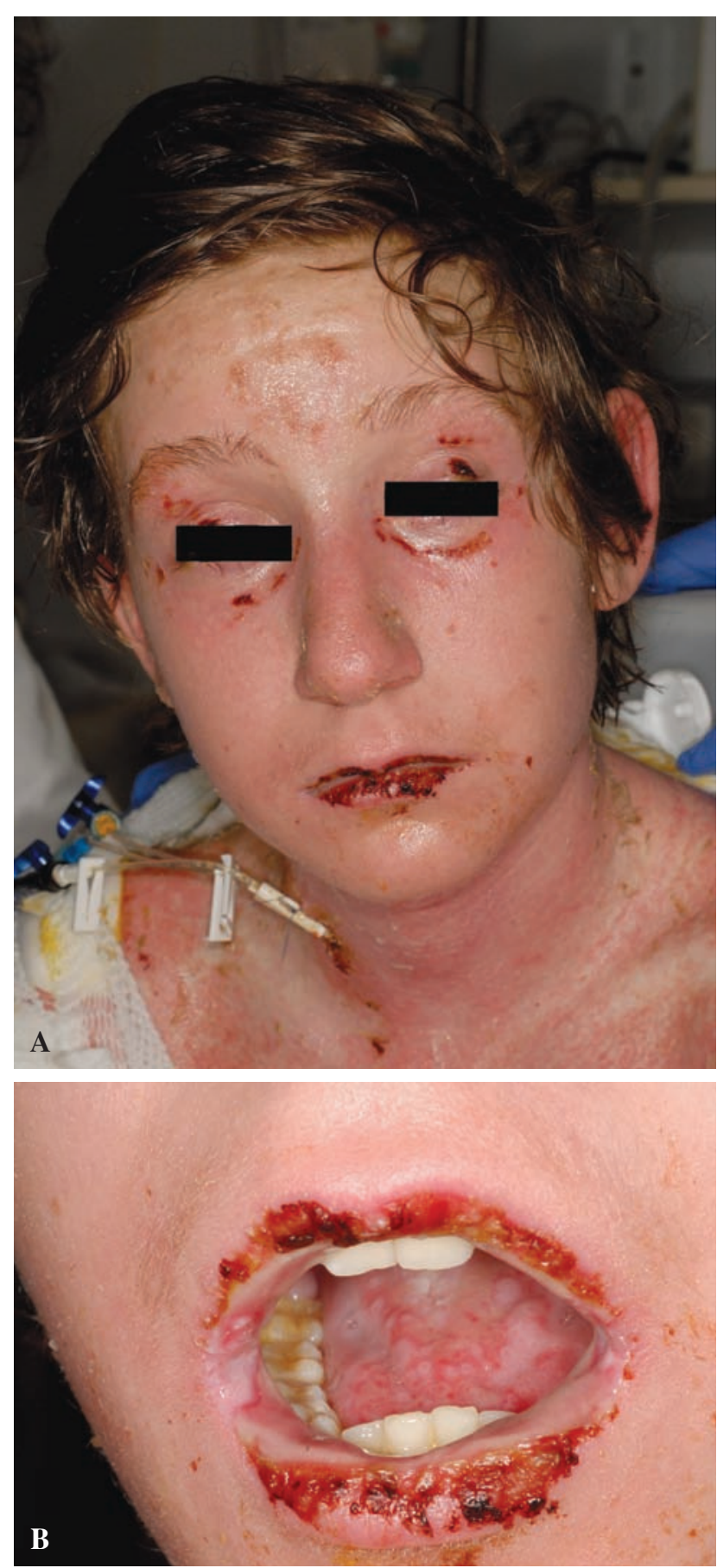

2. A, B. ábra

6. nap. Az erodált területeken haemorrhagiás pörkök láthatóak

végeztünk óvatos, kíméletes napi kötéseket. Kezdetben az ellátás alatt folyamatos, majd a kötözésekhez alkalmi kombinált intravénás sedato-analgesia volt szükséges, de 6 nap elteltével már fájdalomcsillapítás nélkül is kezelhetố volt a beteg. A behámosodott bôrterületek ápolására emolliens készítményt alkalmaztunk. Az ajak és a genitáliák területére Bactroban-os borosalicyl kenőcs került, a szájnyálkahártya kezelésére solutio anaestheticát, nystatinos bórax-glicerin ecsetelőt, illetve a szájhigiéné fenntartása céljából hígított chlorhexidine oldatos öblítést alkalmaztunk. Naponta került sor szemészeti szakvizsgálatra és kezelésre. A szemzugok, szempillák környékét rendszeresen tisztítottuk fiziológiás sóoldattal átitatott vattapálcával, lokálisan antibiotikus és kortikoszteroid tartalmú szemcseppet és szemkenőcsöt, valamint nedvesítő szemgélt használtunk,

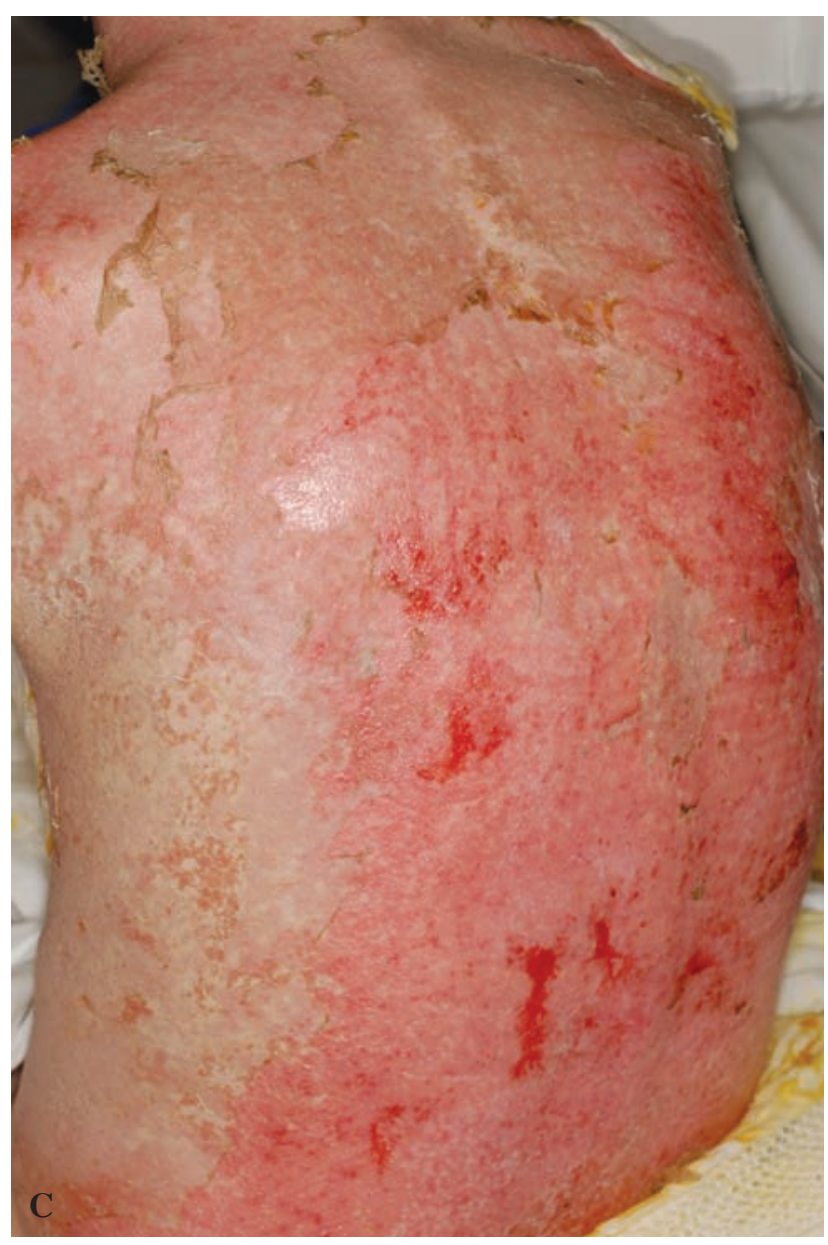

C. ábra

6. nap. Az erodált területeken haemorrhagiás pörkök láthatóak

az áthajlások ellenőrzése naponta több alkalommal helyi érzéstelenítésben, üvegpálcával történt.

Észlelése során a bőrről, a szájüregből, az orr-garatból, kötőhártyáról történô leoltások eredménye negatív lett, haemokultura vizsgálat ugyancsak negatív eredménnyel zárult. Az invazív vérnyomásértékek, a laboratóriumi paraméterek és a klinikai kép alapján a beteg vitálisan mindvégig stabil volt, a szájnyálkahártya tünetek javulását követően fokozatosan visszaálltunk az enterális táplálásra. A gyermek állapota összességében igen gyorsan javult, mind a szisztémás, mind a helyi kezeléseket fokozatosan leépítettük, a felvételét követô 12 . napon gyógyultan távozott otthonába (1-5. ábra).

\section{Megbeszélés}

A TEN vagy Lyell-szindróma (Alan Lyell, 1956) akut, súlyos, életet veszélyetetô, a masszív keratinocyta necrosis miatt kiterjedt, a testfelszín 30\%-át meghaladó bőr- és nyálkahártya denudációval járó kórkép, amelynek hátterében az esetek túlnyomó többségében gyógyszeres kiváltó eredet feltételezhetô. Lefolyása kiszámíthatatlan, igen magas mortalitási arány jellemző. Előfordulási gyakorisága a teljes populációt tekintve 0.4-1.8:1000000, enyhe nôi túlsúly figyelhetô meg (1-5). A kórkép gyermekkorban is igen ritka, azonban újszülötteknél, csecsemőknél, kisgyermekeknél, serdülő korosztályban egyaránt elófordulhat. Ma már közel 200 gyógyszerrôl ismert, hogy felelős lehet a TEN kiváltásáért, azonban a leggyakoribb kiváltó ténye- 


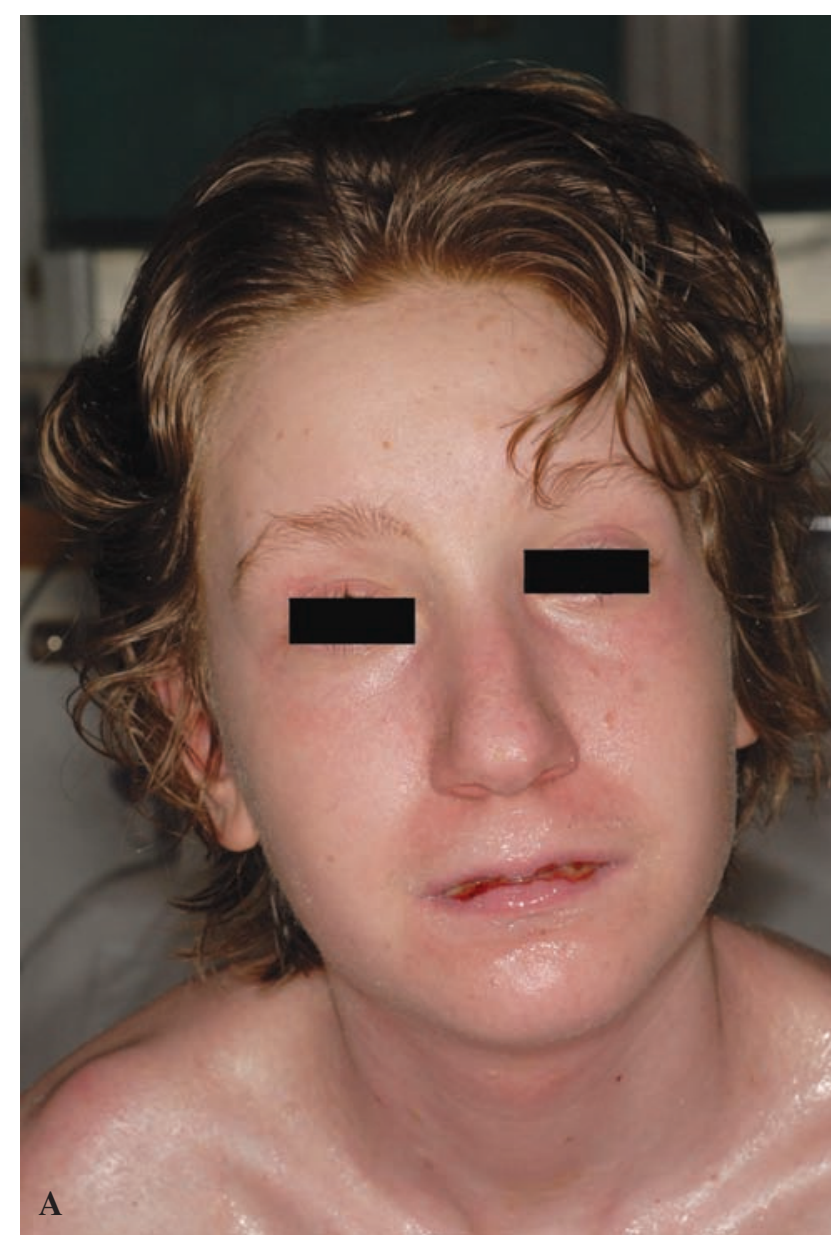

3. A, B, C ábra

11. nap. A klinikai tünetek jelentôs javulása észlelhetố valamennyi régióban, a lepedékkel, pörkkel fedett területetek kiterjedése csökkent az ajak- és szájnyálkahártya területén, a hát területén szinte teljes reepithelizáció látható

zők egyes antiepileptikumok (carbamazepin, phenytoin, phenobarbitál, lamotrigin), penicillin származékok, sulfonamid származékok, non-szteroid gyulladáscsökkentôk, illetve az allopurinol. A gyógyszerek bevezetését követôen általában az elsô 8 hét során (leggyakrabban 4-28 nap után) alakul ki a súlyos adverz reakció, a hosszabb felezési idejú gyógyszerek esetén nagyobb valószínússéggel (3-11).

Patomechanizmusa nem teljesen tisztázott, azonban a gyógyszer, illetve gyógyszermetabolitok által beindított immunológiai reakció eredményeként aktiválódott specifikus cytotoxikus T-sejtek igen fontos szerepet játszanak a hámsejtek károsodásában, emellett a TNF- $\alpha$, IFN- $\gamma$, IL-2 fokozott expressziója révén közvetített, illetve a Fas-FasL interakció révén létrejövő keratinocyta apoptosis is szerepet játszik benne $(1,2)$. Ma már jól ismert a genetikai predispozíció, bizonyos HLA típusok hajlamosító szerepe, illetve egyes FasL polymorphizmusok hatása a kórkép kialakulásában és pathomechanizmusában (3-5).

A bớr- és nyálkahártya tüneteket gyakran változatos, nem specifikus általános tünetek elózik meg, úgy, mint
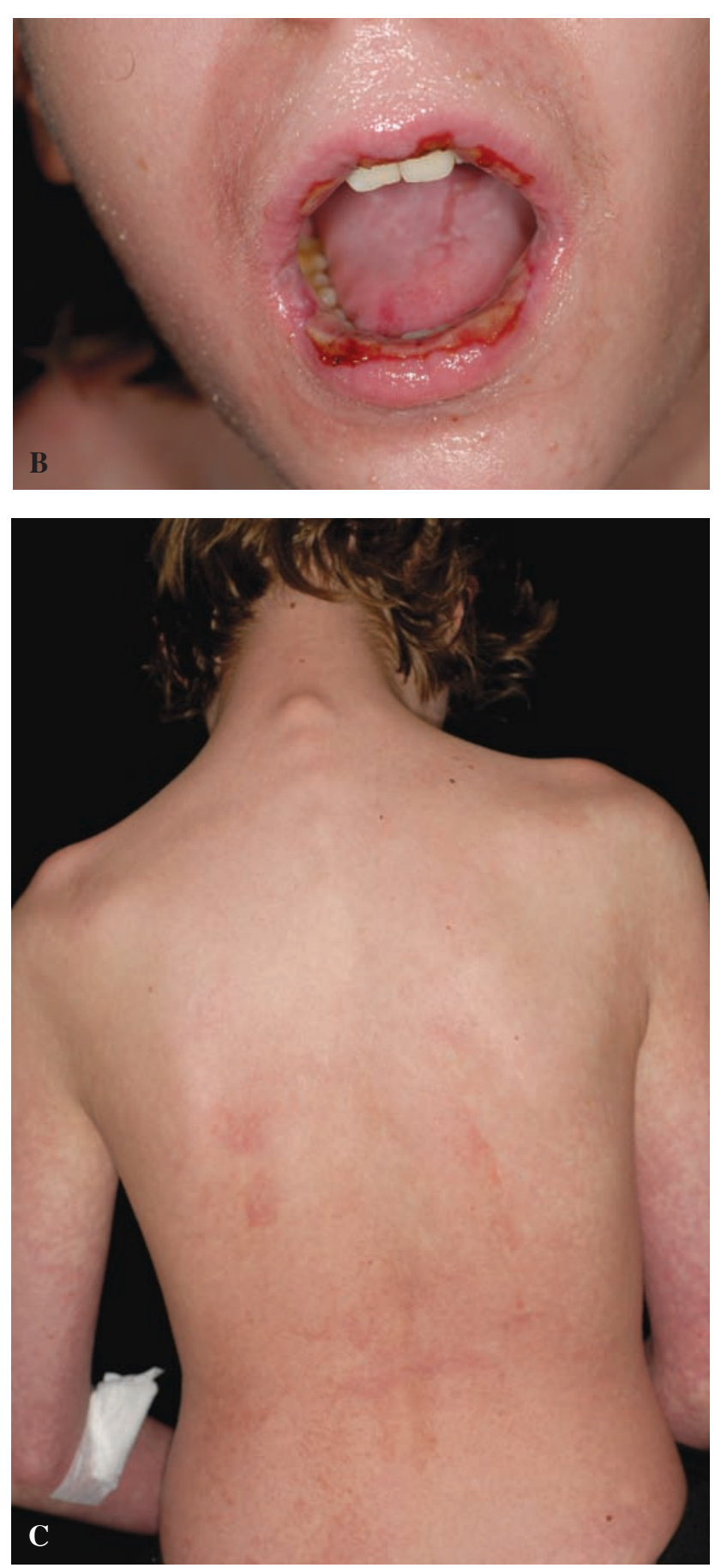

\section{B, C ábra}

11. nap. A klinikai tünetek jelentős javulása észlelhetó valamennyi régióban, a lepedékkel, pörkkel fedett területetek kiterjedése csökkent az ajak- és szájnyálkahártya területén, a hát területén szinte teljes reepithelizáció látható

fejfájás, rossz közérzet, gyengeségérzés, láz, orrfolyás, köhögés, torokfájás, hányinger, hasi, mellkasi, izom vagy ízületi fájdalom. A nyálkahártya tünetek gyakran megelózik a bőrtünetek megjelenését. Általában az ajak, a nyelv, a buccális, az orr, a genitális, a rectális nyálkahártya, conjunctiva érintettség jellegzetes, emellett azonban a mélyebb oropharyngeális, gastrointestinális, tracheobronchi- 

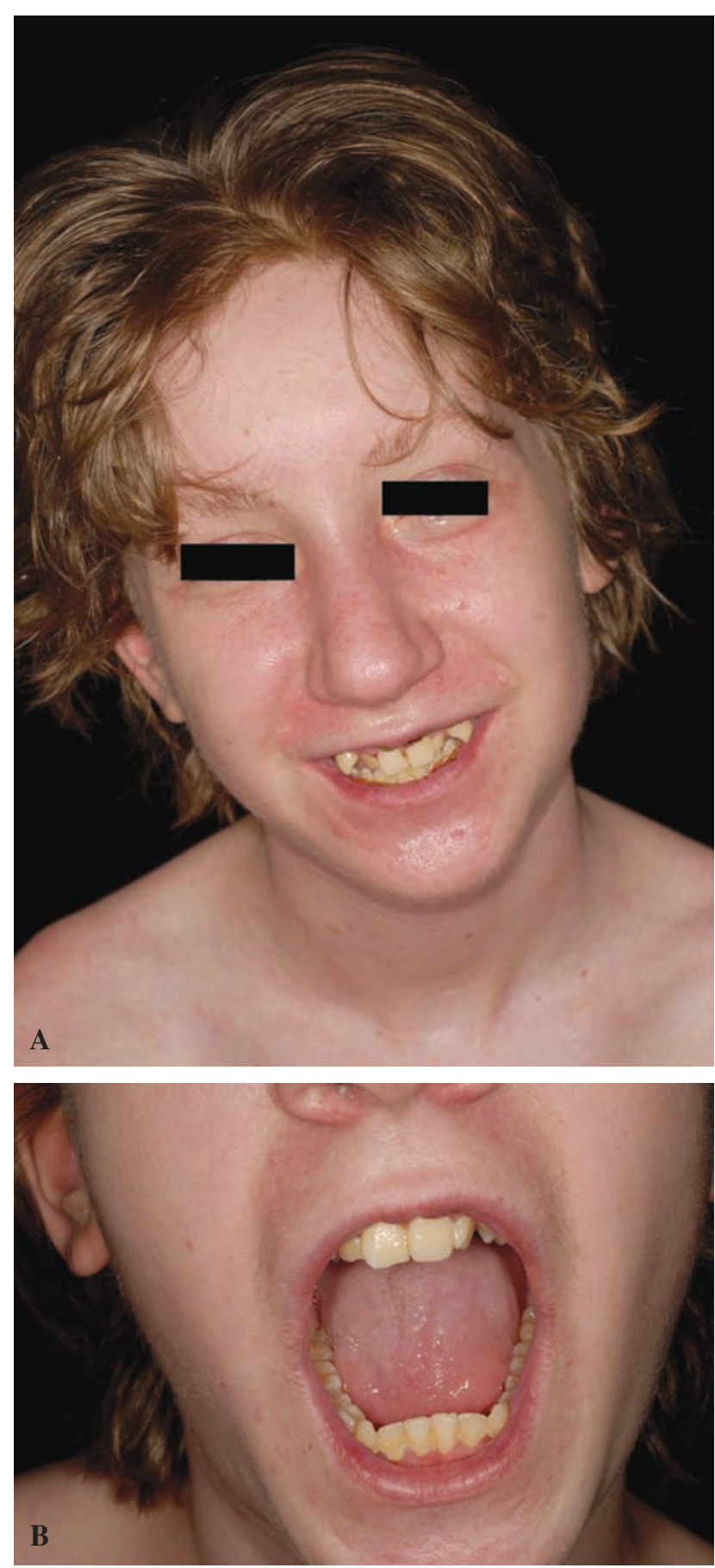

4. A, B ábra

24. nap, kontroll vizsgálat.

Teljesen tünetmentes, gyógyult állapot

ális felszínek károsodása is előfordulhat $(3-5,12)$. Típusosan igen fájdalmas, gyakran lepedékkel, később haemorrhagiás pörkkel fedett superficiális eroziók alakulnak ki, jelentős evési, ivási, vizelési és székelési nehezítettséget okozva a betegnek. A bőrtünetek általában erythémás, helyenként purpuriform jellegû maculosus, maculopapulosus exanthema, vagy atípusos target-léziók formájában jelentkeznek elôször a fej-nyaki régióban, a törzs felsô részén, illetve a felsô végtagok proximális részén, majd gyakran progrediálnak, konfluálnak. A tünetek diffúz, fáj-

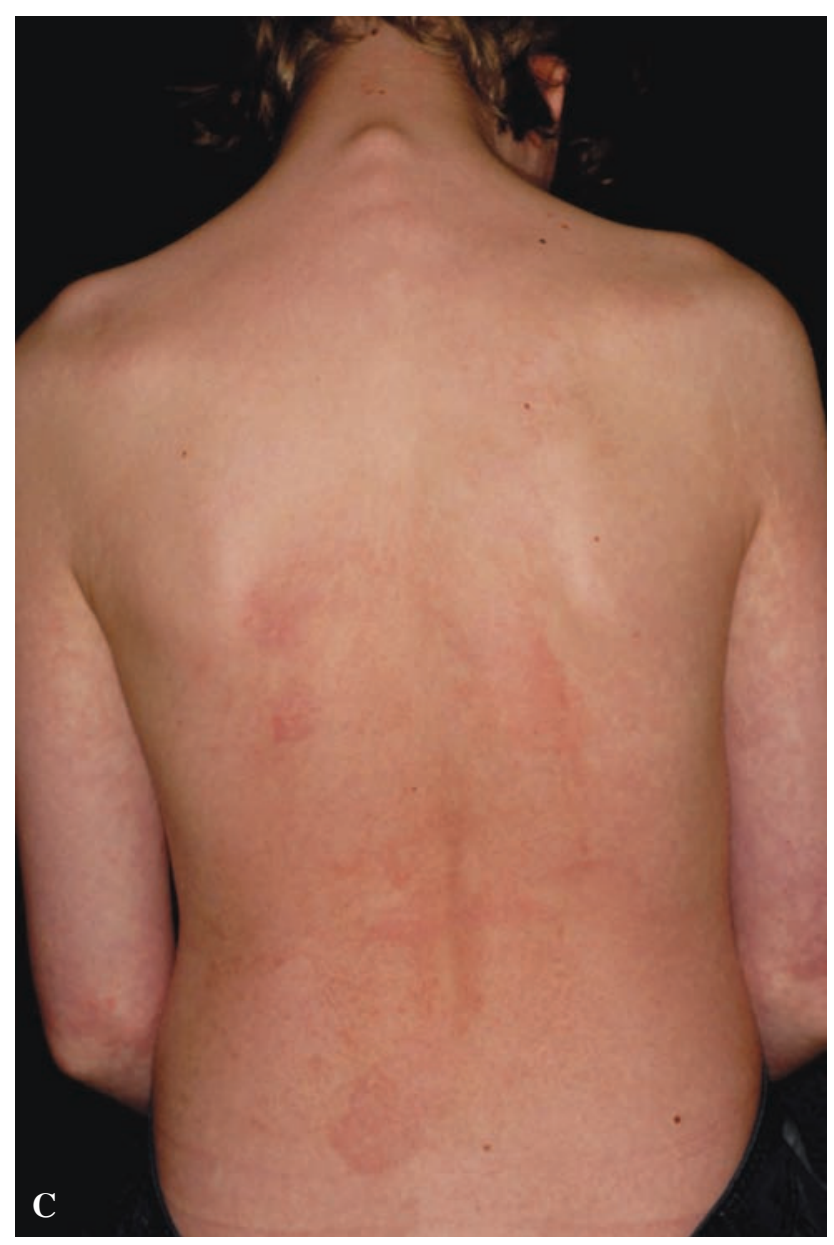

4. C. ábra

24. nap, kontroll vizsgálat.

Teljesen tünetmentes, gyógyult állapot

dalmas erythroderma képében is jelentkezhetnek. A kialakuló hólyagok igen sérülékenyek, a hám felső része „letörölhető", rövid idő alatt masszív denudáció alakulhat ki (3-5).

Differenciál diagnosztikai szempontból az exfoliatív toxint termelő Staphylococcus aureus által előidézett „forrázott bőr szindróma", autoimmun hólyagos betegségek, akut graft-versus-host betegség, egyéb súlyos gyógyszer adverz reakciók (generalizált bullosus fix gyógyszerexanthema, akut generalizált exanthematosus pustulosis, gyógyszer indukálta erythroderma, DRESS-szindróma) jöhetnek szóba (1,3-5).

A leggyakoribb szisztémás komplikációk a folyadék-elektrolit háztartás felborulásának, illetve az infekciók következményeinek tarthatóak, a halálozások jelentős részét a szepszis eredményeként kialakuló sokszervi elégtelenség okozza (8). Pneumonitis, haematuria, nephritis, progresszív veseelégtelenség, oesophagus és trachea ulceratio, gastrointestinalis vérzések, lymphadenopathia, hepatosplenomegalia, myocarditis, arthritis, arthralgia egyaránt kialakulhatnak. Felnőttekben az adekvát intenzív ellátás mellett is a kórkép letalitása $30-50 \%$, gyermekekben ennél lényegesen jobb prognózis jellemzô. A 2000-ben összeállított ún. SCORTEN rendszer jól használható a 


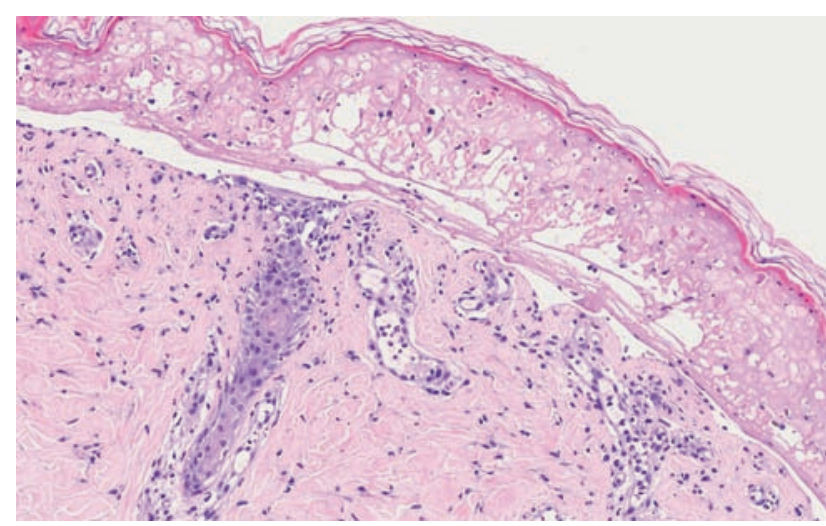

5. ábra

Szövettani vizsgálat.

Mikroszkópos vizsgálattal a felszíni hámban

kiterjedt necrosis, necrobiosis látszódik,

a hám subepidermális lokalizációban levált az irháról.

A hámban, a necroticus keratinocyták körül, valamint az irha felsố részében,

fóként a papilláris erek körül enyhe fokú mononucleáris beszúrôdés mutatkozik

prognózis megbecslésére, egyenlőre azonban gyermekekre adaptált formája nem áll rendelkezésre (3-5).

A bőrgyógyászati szövődmények közül leggyakrabban pigmentációs rendellenesség, dyschromia, hypo-és hyperpigmentált területek megjelenése észlelhetô, ez az eltérés gyakran évekig fennáll (13-15). A betegek egy részénél eruptívan nagyszámú festéksejtes naevus megjelenését észlelik. Körömelváltozások, onychomadesis, onycholysis, onychodystrophia, illetve telogen effluvium is előfordulhat. Súlyos, kiterjedt nyálkahártyaérintettség esetén oesophageális, vaginális, urethralis és analis stricturák és stenosisok is kialakulhatnak, amelyek sebészeti megoldása is szükséges lehet $(3-5,12)$.

A szemészeti szövődmények igen gyakoriak, mind a betegség akut fázisában, mind hosszú távon, a betegek mintegy 40\%-át érintik, emiatt fontos hangsúlyozni a korán bevezetett és rendszeres szemészeti ellenőrzés fontosságát. Az akut szemészeti ellátás során a lokális antibiotikumos készítmények megelőzik az infekciók kialakulását és a szteroid tartalmú szemcseppek csökkentik az akut gyulladást, ezek mellett szükség van megfelelő lubrikáns készítmények rendszeres használatára is $(6,12-14,16,17)$. A lubrikánsok jelentôs segítséget nyújthatnak a késői szövődmények megelőzésében és kezelésében is $(11,12,15$, 16, 18, 19). Adhéziók észlelése esetén naponta szükséges a fornix területének tisztítása, debridement, illetve üvegpálcácal adhézió-lízis végzése. A szakirodalomban kiváló eredményekrôl számolnak be amnion membrán beültetéséről, mind a rövid, mind a hosszú távú komplikációk prevenciójában $(17,20)$.

A Lyell-szindróma kezelésére vonatkozó útmutatók, ajánlások nem egységesek, jelentős különbségeket találunk az egyes intenzív terápiás centrumok gyakorlata között. Az irodalmi adatok egységesek abból a szempontból, hogy a kórkép kezelésében, a további progresszió megakadályozásában elsôrendú a kiváltó tényezôként szóba jövő gyógyszer, gyógyszerek azonnali elhagyása, ez gyermekek esetében viszonylag könnyebben kivitelezhető (3-6). Rendkívül fontos a hatékony szupportív kezelés biztosítása, ehhez a betegeket speciális, intenzív szakellátást nyújtó égési centrumban, vagy intenzív osztályon kell ellátni $(21,22)$. Az első észlelés során fontos és meghatározó az érintett testfelszín kiterjedésének pontos felmérése. Az intenzív ellátás magában foglalja a vitális paraméterek folyamatos monitorizálását, a folyadék-elektrolit és hôháztartás stabilizálását, a megfelelő, szükség esetén parenterális táplálás bevezetését, a szoros infekciókontrollt, a bőr és nyálkahártya felszínek helyi kezelését, az antikoaguláns kezelés bevezetését és a hatékony fájdalomcsillapítást. A pótolandó folyadék mennyiségét az óradiurézis, valamint az aktuális vitális és laborparaméterek alapján kell kiszámolni; meghatározásakor nem teljesen használható az égett betegek ellátási protokollja, hiszen Lyell-szindrómában a kapilláris áteresztés mértéke kisebb (1, 3-5, 11, 23-25). Az intenzív szakellátás mellett lényeges a rendszeres fül-orr-gégészeti, szemészeti, bőrgyógyászati, urológiai, nőgyógyászati szakvizsgálat és ellátás, valamint a megfelelő fizioterápia és gyógytorna bevezetése is (26).

A TEN specifikus kezelésére vonatkozóan egységes, evidenciákon alapuló, standardizált protokollok nem állnak rendelkezésre sem a felnôtt, sem a gyermekpopulációban (1, 3-5, 19). Ebben részben szerepet játszik az a tény, hogy igen ritka, súlyos betegségrôl van szó, így randomizált, kontrollált, nagyszámú beteganyagot felölelő klinikai vizsgálatok elvégzésére nincsen lehetőség. A legtöbb adat az intravénás kortikoszteroid és IVIG alkalmazását illetően áll rendelkezésre, egyes eset riportokban a kombinált szteroid + IVIG kezelésról számolnak be. Az IVIG hatékonyságára vonatkozó adatok is ellentmondóak $(2,27,28)$. A pro-és retrospektív vizsgálatok, eset riportok eredményei nehezen vethetôek össze, hiszen jelentős különbségeket találunk az immunglobulin készítmény típusát, dózisát és a kezelés idôtartamát illetően is. Gyermekeknél alacsony és magas dózisú IVIG (0.05-1 g/tskg; 2-5 napon át) kezelésrôl egyaránt vannak adatok, azonban az optimális kezelési dózis nem ismert $(3-5,26,29,30)$.

Az IVIG hatását feltételezhetően a Fas-ligand mediált keratinocyta apoptózis gátlásán, a keringő immunkomplexek eliminációján, a cytokin szekréció modulálásán, az Fc receptorok funkcionális gátlásán, a celluláris immunválasz regulációján keresztül fejti ki, emellett a szövődményes infekciók kialakulásának veszélyét is csökkenti (31). A estek jelentôs részében az IVIG kezelés mellett gyermekpopulációban a morbiditási és mortalitási arány, valamint a hospitalizáció időtartalmának csökkenését, a reepithelizáció folyamatának felgyorsulását észlelték, mellékhatások ritkán fordultak elő (14, 21, 30, 32-35).

Az IVIG-hez hasonlóan nem egységes a szakirodalom a szteroidok használatát illetően sem (19). Főleg a későn, nagy dózisban, elhúzódóan alkalmazott kortikoszteroid ke- 
zelések kapcsán volt megfigyelhetô gyakrabban fertőzéses, septikus szövődmények megjelenése. Amennyiben szteroid kezelés bevezetése mellett döntünk, célszerú a betegség korai szakaszában, nagy dózisban, rövid ideig alkalmazni. Viszonylag kevés adat áll rendelkezésre egyéb készítmények, így a cyclosporin $\mathrm{A}$, az $\mathrm{N}$-acetylcystein, a pentoxiphyllin, az ulinastatin, a cyclophosphamid, a mycophenolate mofetin, a TNF- $\alpha$ gátlók, a granulocyta kolónia-stimuláló faktor, a plasmapheresis alkalmazásával kapcsolatban (2, 26, 36-41).

Fontos nagy hangsúlyt fektetni a megfelelő bőrgyógyászati helyi kezelésekre, hiszen az epidermális barrier funkció súlyos károsodásának igen komoly következményei vannak. A kötéscseréket steril körülmények között, kíméletesen kell elvégezni, hatékony fájdalomcsillapítás mellett. Kisebb kiterjedésû hámfosztott területek esetén tisztítást követôen használhatunk modern, intelligens, non-adhezív kötszereket, kiterjedtebb léziók esetén borogatást követően hámosító kenőccsel impregnált steril gézlapokat, biológiai kötszereket, illetve sok esetben szükséges lokális antibiotikum készítmények (bacitracin, mupirocin) használata. Fontos az érintett bőrfelület kíméletes tisztítása langyos, közel testhőmérsékletûre melegített steril fiziológiás sóoldattal és a necrotikus hámrészletek óvatos eltávolítása, késóbb - amennyiben a beteg általános állapota megengedi - fürdetése antiseptikus készítménnyel $(3-5,11,13,15,18,23,42)$.

\section{Konklúzió}

A TEN a gyermekpopulációban is szerencsére igen ritka, azonban rendkívül súlyos kórkép. Kezelésében legfontosabb a kiváltó gyógyszer elhagyása, valamint a prompt, agresszív, multidiszciplináris szupportív terápia alkalmazása. A specifikus kezelést illetően nincsenek egységes szakmai irányelvek, azonban az irodalmi adatok áttekintése alapján elmondható, hogy a legtöbb tapasztalat az intavénás kortikoszteroid és IVIG kezelés kapcsán áll rendelkezésre. Esetünkben a kombinált nagy dózisú szteroid és IVIG kezelés mellett a tünetek gyors javulását észleltük, a hospitalizáció idôtartama alatt, illetve az ezt követô kontroll idôszakban szövődmény jelentkezését nem észleltük. Természetesen a jövőben további vizsgálatok és klinikai tapasztalatok szükségesek ahhoz, hogy ezen igen súlyos kórkép kezelésére vonatkozó egyértelmú ajánlások körvonalazódjanak.

\section{IRODALOM}

1. Gerdts B., Vloemans A. F., Kreis R. W.: Toxic epidermal necrolysis: 15 years' experience in a Dutch burns centre. J Eur Acad Dermatol Venereol (2007) 21(6), 781-788.

2. Khalili B., Bahna S. L.: Pathogenesis and recent therapeutic trends in Stevens-Johnson syndrome and toxic epidermal necrolysis. Ann Allergy Asthma Immunol (2006) 97(3), 272-280.

3. Burgdorf, W. H. C., Plewig, G., Wolff, H. H., Landthaler, M.: Braun-Falco's Dermatology. 3rd ed. Heidelberg: Springer Medizin Verlag; 2009. 1712 p.

4. Bolognia, J. L., Jorizzo, J. L., Schaffer, J. V.: Dermatology. 3rd ed. St.Louis: Mosby/Elsevier; 2012. 2572 p.

5. Paller, A. S., Mancini, A. J.: Hurwitz Clinical Pediatric Dermatology. 4th ed. Elsevier Saunders; 2011. 632 p.

6. Dore J., Salisbury R. E.: Morbidity and mortality of mucocutaneous diseases in the pediatric population at a tertiary care center. $\mathrm{J}$ Burn Care Res (2007) 28(6), 865-870.
7. Hirsch L. J., Weintraub D. B., Buchsbaum R. és mtsai.: Predictors of Lamotrigine-associated rash. Epilepsia (2006) 47(2), 318322.

8. Barvaliya M., Sanmukhani J., Patel T. és mtsai.: Drug-induced Stevens-Johnson syndrome (SJS), toxic epidermal necrolysis (TEN), and SJS-TEN overlap: a multicentric retrospective study. J Postgrad Med (2011) 57(2), 115-119.

9. Forman R., Koren G., Shear N. H.: Erythema multiforme, Stevens-Johnson syndrome and toxic epidermal necrolysis in children: a review of 10 years' experience. Drug Saf (2002) 25(13), 965-972.

10. Schlienger R. G., Shapiro L. E., Shear N. H.: Lamotrigine-induced severe cutaneous adverse reactions. Epilepsia (1998) 39 Suppl 7S22-S26

11. Wolkenstein P. E., Roujeau J. C., Revuz J.: Drug-induced toxic epidermal necrolysis. Clin Dermatol (1998) 16(3), 399-408.

12. Sheridan R. L., Schulz J. T., Ryan C. M. és mtsai.: Long-term consequences of toxic epidermal necrolysis in children. Pediatrics (2002) 109(1), 74-78.

13. Elkharaz S., Abdel-Razek E.M., Eldin A. és mtsai.: Severe bullous skin diseases: analysis of seven children managed in a burns unit. Ann Burns Fire Disasters (2006) 19(4), 180-187.

14. Kim K. J., Lee D. P., Suh H. S. és mtsai.: Toxic epidermal necrolysis: analysis of clinical course and SCORTEN-based comparison of mortality rate and treatment modalities in Korean patients. Acta Derm Venereol (2005) 85(6), 497-502.

15. Spies M., Sanford A. P., Aili Low J. F. és mtsai.: Treatment of extensive toxic epidermal necrolysis in children. Pediatrics (2001) 108(5), 1162-1168.

16. Chang Y. S., Huang F. C., Tseng S. H. és mtsai.: Erythema multiforme, Stevens-Johnson syndrome, and toxic epidermal necrolysis: acute ocular manifestations, causes, and management. Cornea (2007) 26(2), 123-129.

17. Shammas M. C., Lai E. C., Sarkar J. S. és mtsai.: Management of acute Stevens-Johnson syndrome and toxic epidermal necrolysis utilizing amniotic membrane and topical corticosteroids. Am J Ophthalmol (2010) 149(2), 203-213.

18. Mamishi S., Fattahi F., Pourpak Z. és mtsai.: Severe cutaneous reactions caused by barbiturates in seven Iranian children. Int J Dermatol (2009) 48(11), 1254-1261.

19. Prendiville J. S., Hebert A. A., Greenwald M. J. és mtsai.: Management of Stevens-Johnson syndrome and toxic epidermal necrolysis in children. J Pediatr (1989) 115(6), 881-887.

20. Gregory D.G.: Treatment of acute Stevens-Johnson syndrome and toxic epidermal necrolysis using amniotic membrane: a review of 10 consecutive cases. Ophthalmology (2011) 118(5), 908-914.

21. Tristani-Firouzi P., Petersen M. J., Saffle J. R. és mtsai.: Treatment of toxic epidermal necrolysis with intravenous immunoglobulin in children. J Am Acad Dermatol (2002) 47(4), 548-552.

22. McGee T., Munster A.: Toxic epidermal necrolysis syndrome: mortality rate reduced with early referral to regional burn center. Plast Reconstr Surg (1998) 102(4), 1018-1022.

23. Khoo A. K., Foo C. L.: Toxic epidermal necrolysis in a burns centre: a 6-year review. Burns (1996) 22(4), 275-278.

24. Green D., Law E., Still J. M.: An approach to the management of toxic epidermal necrolysis in a burn centre. Burns (1993) 19(5), 411-414.

25. Parsons J. M.: Management of toxic epidermal necrolysis. Cutis (1985) 36(4), 305-1.

26. Arca E., Kose O., Erbil A. H. és mtsai.: A 2-year-old girl with Stevens-Johnson syndrome/toxic epidermal necrolysis treated with intravenous immunoglobulin. Pediatr Dermatol (2005) 22(4), 317-320.

27. Huang Y. C., Li Y. C., Chen T. J.: The efficacy of intravenous immunoglobulin for the treatment of toxic epidermal necrolysis: a systematic review and meta-analysis. Br J Dermatol (2012) 167(2), 424-432.

28. Ferrandiz-Pulido C., Garcia-Fernandez D., Dominguez-Sampedro P. és mtsai.: Stevens-Johnson syndrome and toxic epidermal necrolysis in children: a review of the experience with paediatric patients in a university hospital. J Eur Acad Dermatol Venereol (2011) 25(10), 1153-1159. 
29. Pasic S.: Intravenous immunoglobulin in toxic epidermal necrolysis. Int J Dermatol (2006) 45(9), 1117-1118.

30. Habib A., Pasha W., Raza N.: Treatment of toxic epidermal necrolysis (TEN) with low dose intravenous immunoglobulin in child. J Coll Physicians Surg Pak (2010) 20(3), 205-207.

31. Viard I., Wehrli P., Bullani R. és mtsai.: Inhibition of toxic epidermal necrolysis by blockade of CD95 with human intra venous immunoglobulin. Science (1998) 282(5388), 490493.

32. El Naggari M. A., Javad H., Chacko A. P. és mtsai.: Intravenous immunoglobulin in the treatment of vancomycin-induced toxic epidermal necrolysis. Sultan Qaboos Univ Med J (2013) 13(1), 132-136.

33. Mayorga C., Torres M.J., Corzo J. L. és mtsai.: Improvement of toxic epidermal necrolysis after the early administration of a single high dose of intravenous immunoglobulin. Ann Allergy Asthma Immunol (2003) 91(1), 86-91.

34. Prins C., Vittorio C., Padilla R. S. és mtsai.: Effect of high-dose intravenous immunoglobulin therapy in Stevens-Johnson syndrome: a retrospective, multicenter study. Dermatology (2003) 207(1), 96-99.

35. Prins C., Kerdel F. A., Padilla R. S. és mtsai.: Treatment of toxic epidermal necrolysis with high-dose intravenous immunoglobulins: multicenter retrospective analysis of 48 consecutive cases. Arch Dermatol (2003) 139(1), 26-32.
36. Aihara Y., Ito R., Ito $S$. és mtsai.: Toxic epidermal necrolysis in a child successfully treated with cyclosporin A and methylprednisolone. Pediatr Int (2007) 49(5), 659-662.

37. Scott-Lang V., Tidman M., McKay D.: Toxic Epidermal Necrolysis in a Child Successfully Treated with Infliximab. Pediatr Dermatol (2012 Oct 16) - Epub ahead of print

38. Sanclemente G., De la Roche C. A., Escobar C. E. és mtsai.: Pentoxyfylline in toxic epidermal necrolysis and Stevens-Johnson syndrome. Int J Dermatol (1999) 38(11), 878-879.

39. Egan C. A., Grant W.J., Morris S. E. és mtsai.: Plasmapheresis as an adjunct treatment in toxic epidermal necrolysis. J Am Acad Dermatol (1999) 40(3), 458-461.

40. Chaidemenos G. C., Chrysomallis F., Sombolos K. és mtsai.: Plasmapheresis in toxic epidermal necrolysis. Int $\mathrm{J}$ Dermatol (1997) 36(3), 218-221.

41. Goulden V., Goodfield M. J.: Recombinant granulocyte colonystimulating factor in the management of toxic epidermal necrolysis. Br J Dermatol (1996) 135(2), 305-306.

42. Palmieri T. L., Greenhalgh D. G., Saffle J. R. és mtsai.: A multicenter review of toxic epidermal necrolysis treated in U.S. burn centers at the end of the twentieth century. J Burn Care Rehabil (2002) 23(2), 87-96.

Érkezett: 2013. 08. 21.

Közlésre elfogadva: 2013. 09. 25. 